\title{
Would You Have Realized?
}

Learning is a game. In this sense, Dermatology + Psychosomatics regularly presents you the Psychodermatology Quiz. Other colleagues are welcome to submit their own contributions.

\author{
C.-M. Höring ${ }^{\mathrm{a}} \quad$ G. Nist ${ }^{\mathrm{b}}$ \\ a Dermatological Practice \\ ${ }^{b}$ Department of Dermatology, City Hospital Bad Cannstatt, Stuttgart
}

\section{Case Description}

Mrs. W, a 39-year-old nurse, presents to the hospital in winter 2001 with CREST-Syndrome (calcinosis, Raynaud's phenomenon, esophageal dysfunction, sclerodactylia, and telangiectasia) with elevated serum antinuclear antibodies. The patient is separated from her psychotic and aggressive husband.

Her complaints began 1985 with Raynaud's phenomenon of her fingers. For one year before hospitalization, she has been suffering from badly healing wounds on the fingertips, and during that time she has lost $10 \mathrm{~kg}$ of weight. Now, the perfusion of her legs and feet is significantly reduced causing much pain, which is relieved when she is walking slowly. Sleeping is only possible in an upright position, letting her feet hang out of the bed. One week before the psychosomatic interview, when Mrs. W. was hospitalized, she showed increased swelling of both hands and feet and had significant edema in her legs and feet, partly also calcinosis cutis. Both feet showed loss of sensitivity, the toes had turned purple; over the past weeks the second toe of her left foot has turned black. Hands and fingers were swollen, with sclerodactylia and healed wounds of ratbite necroses.

Medical family history: one brother suffers from Lupus erythematodes, a sister of Sjögren's sydrome.

The ward physician had already realized that the beginning of the patient's problems dates back to a time, when the patient had a lot of psychosocial problems. In countertransference she expresses anger, because Mrs. W. won't stop smoking although this would be necessary for therapy. A compliance problem seems to develop.

When Mrs. W. presents her condition in the psychosomatic counseling session, she first describes her symptoms rather unemotionally. She does not really complain, she just tells about her pain, the difficulties in running her household, the impossibility to work as a nurse in a surgical ward like she did before. When she is told that she is diagnosed with a disease that none of her friends or her family might ever have heard of and that this could mean that she could feel quite lonely, she begins to weep.

In 2000, when the more severe symptoms began, her husband had been suicidal. He only survived because she had wanted to surprise him and had returned earlier than planned from a short holiday. Never before had she noticed that he was depressed. It seemed to have been an acute psychotic episode. Since then he has not been like he was before: he is aggressive and does not take his psychiatric medication regularly. He reproached her for being responsible for his illness: 'you made me ill!' At this time her autoimmune parameters increased distinctly. The diagnosis of her disease was made at a time when her husband suffered from another episode of acute psychosis and when originally a coercive psychiatric hospitalization had been planned.

The illness of her husband was not the only burden Mrs. W. had to carry. She had lost her father in March 2000 in a tragic accident. Her mother had died a year before. One brother of her husband committed suicide 6 years ago. Her favorite niece developed diabetes and fell into a coma.

Mrs. W. herself has always been a healthy, vital and cheerful woman. She used to work as a nurse in developing countries for some years. Now she is depressive, without any joy in life, and feels guilty because of her husband whom she wants to divorce.

Asked about her nicotine abuse, she replies that at this moment it would be impossible for her to stop smoking, since she is too preoccupied.

\begin{tabular}{ll}
\hline KARGER & @ 2002 S. Karger GmbH, Freiburg \\
$\begin{array}{l}\text { Fax +49 7614520714 } \\
\begin{array}{l}\text { E-mail Information@Karger.de } \\
\text { www.karger.com }\end{array}\end{array}$ & Accessible online at: \\
www.karger.com/journals/dps
\end{tabular}




\section{Questions}

1) What are your first ideas from a psychodynamic point of view?

2) Which psychopathological diagnosis would you suggest?

3) Can you identify a conflict?

4) Which therapy would you recommend in addition to the dermatological somatic treatment, which procedure seems efficient?

\section{Answers}

1) The coincidence of psychosocial problems with the onset of the disease is obvious. Mrs. W. develops an autoaggressive disorder when her husband tries to commit suicide. Considering that she has also lost her father through an accident only a few months before, she might have perceived her husbands' action as highly aggressive towards her - in fact he himself reproaches her for being aggressive and makes her responsible for his psychosis. Mrs. W. had not been able to repudiate his accusations, she was still too worried by the loss of both her parents. It is not known whether she is prone to feeling guilty or whether she had depressive attacks before. She cannot remember any similar reaction before this incidence. The autoaggressive disorder seems to solve the problem by directing aggressions against herself - since she is not allowed to verbalize them against her husband.

2) Posttraumatic stress disorder PTSD (ICD F 43.1) with depressive symptoms and somatization (ICD F 54.0)

3) It seems obvious that a conflict exists when dealing with her aggressions. In fear of own destructive impulses and because the husband makes her responsible for his suicidal impulses she has to restrain her feelings, afraid of being a 'murderess' in case he tries again; her husband is still very depressive and a high-risk patient.

In addition, Mrs. W. had to bear the sudden loss of her parents. She had not been allowed to say good-bye to her father and in fact has crude fantasies about his death. She had found her husband in a huge pool of blood, a traumatic event to everyone. In this kind of situation normal psychic defense mechanisms fail. It is the sort of trauma developing a vital discrepancy between highly threatening situational factors and an individual's ability of coping with them, feelings of complete helplessness and of being unprotected, so that the feeling of shock continues. In terms of PTSD classification it is a category 1 trauma. Mrs. W. feels overwhelmed by her memories, she develops a depressive reaction with decreasing interest in her social life and with difficulties to adequately express her feelings; she suffers from sleeping disorders and develops a somatic reaction - part of a posttraumatic stress disorder rather than the expression of unconscious conflicts.
4) Mrs. W. was recommended to accept hospitalization - after receiving dermatological treatment - in a psychosomatic ward where a special trauma-therapy can be offered. This includes supporting therapy, self-stabilizing interventions in combination with different imaginative techniques, e.g., EMDR (eye movement desensitization and reprocessing) or guided affective imagery. It would also be possible to offer this therapy without hospitalization, but at this moment, Mrs. W. seemed to be highly relieved by the idea to have time just for herself and to be protected in a clinical setting instead of being confronted with her husband's problems. Trauma-specific therapy is always very difficult when the traumatic situation persists. It should be possible to treat at least the traumatic loss of her parents and to develop more self-confidence in coping with the actual crisis in her relationship with her husband. The therapy should be continued afterwards under ambulant conditions.

\section{Key Learning Points}

Posttraumatic Stress Disorder (PTSD)

PTSD is characterized by various criteria. Firstly, there is a marked threat to the own body or a traumatic event, which the person experienced him-/herself, or watched in others. The person then reacts with intensive fear, helplessness, or fright/shock. The second criterion refers to the symptoms of intrusive remembrances, burdening dreams, so called flashback reactions, and combined physiological reactions.

Symptoms are, for example, the avoidance of reminding thoughts and feelings, of normal social activities and of situations that may remind of the trauma. Further symptoms are amnesia, loss of interest, feelings of estrangement, loss of normal affective reactions, the idea of a limited future, sleeping disorders, high irritability, loss of concentration, hypervigilance and being easily frightened. The symptoms typically last for more than one month and cause clinically relevant impairment of a normal social life.

In these patients a disturbed regulation of affect-control or impulses, self-inflicting behavior, dissociative tendencies, psychosomatic disorders, feeling of false identity, difficulties in interpersonal relationships, the danger of being victimized, as well as the loss of hope and of former orientation-stabilizing personal convictions can be observed.

\section{Suggested Reading}

Reddemann L: Imagination als heilsame Kraft. Zur Behandlung von Traumafolgen mit ressourcenorientierten Verfahren. Stuttgart, Klett-Cotta, 2001.

Streeck-Fischer A, Sachsse U, Özkan I (Hrsg): Körper Seele Trauma. Göttingen, Vandenhoeck und Ruprecht, 2001 